\title{
sciendo
}

DOI 10.2478/sbe-2020-0040

SBE no. 15(2) 2020

\section{DIGITAL TRANSFORMATION OF CENTRU REGION - ROMANIA. NEEDS ASSESSMENT}

\author{
OGREAN CLAUDIA \\ Lucian Blaga University of Sibiu, Romania \\ HERCIU MIHAELA \\ Lucian Blaga University of Sibiu, Romania
}

\begin{abstract}
:
Competitiveness represents a never-ending moving target for any institution/entity, no matter the level of analysis (micro - companies / public administrations, mezzo - industries / national regions, or macro - countries / world regions); but its determinants (or key success factors) are changing, as ages go by, asking for continuous watch and strategic flexibility. With digital technology nowadays disrupting (almost) every aspect of human life, while framing a new age - of digitalization being both a source of competitiveness (for the industry leaders - whatever the "industry" might be), and (just) a prerequisite for survival (or doing business) for almost everyone else, the European Commission's political priority for 2019-2024 "A Europe fit for the digital age" and the EU's digital strategy aiming for a "digital transformation that will benefit everyone" are of great interest (accentuated by the new pandemic context) for all the EU regions and their institutions/entities. Within this framework, the paper (which is part of a bigger research) aims to perform an overview scan of Centru Region-Romania (mainly by comparison with Romania's other Development Regions and with EU benchmarks) in order to broadly identify its needs for digital transformation, while setting the backgrounds for a more systematic, focused and applied analysis to follow.
\end{abstract}

Key words: Centru Region-Romania; digital transformation; (digital) innovation; (digital) competitiveness; innovation performance

\section{Introduction}

The needs assessment aimed to identify the imperatives of digital transformation for Centru Region-Romania - in line with the Region's strategic directions (http://www.adrcentru.ro/dezvoltare-regionala-cat/pdr-centru-2021-2027/) and in order to connect the Region to the requirements of Digital Europe (https://ec.europa.eu/digital-single-market/en/content/european-digital-strategy). Aspiring to identify as accurately as possible (based on evidence) the gaps between the existing status and the desired one as concerns the practice and/or adoption of digital innovation 
among businesses and public administrations in Centru Region-Romania, the process of needs identification and needs assessment embraced a holistic approach - able to capture from multiple perspectives and sources, and then to cross-sectionally integrate and synthesize the (sometimes contradictory) information gathered.

The endeavor of needs identification was built on the analysis of the complementary perspectives the complex category "needs for digital transformation in Centru Region-Romania" develops: (1) normative needs - against the targets strategically set at regional (Smart Specialization Strategy, Regional Development Plan 2021-2027 and Regional Operational Plan 2021-2027), national and EU level; (2) comparative/relative needs - revealed by the comparative statistical analysis (Centru Region-Romania, Romania, and EU) of relevant indicators; (3) perceived needs - by businesses and administrations - according to their own understandings and perceptions on the potential benefits capitalizing on digital technologies may bring to their organizations; (4) expressed needs - in terms of financial resources businesses and administrations are willing to commit for investments in the field; and (5) future/latent needs - having the potential to become perceived needs as organizations, through their managers, internalize that digital transformation and/or innovation is becoming a prerequisite for survival and development in the smart society of the future.

As part of a bigger research, this paper focuses only on the comparative I relative perspective of the category "needs for digital transformation in Centru RegionRomania"; therefore, the remainder of the paper is organized as follows: section 2 makes a brief description of Centru Region-Romania, section 3 investigates Romania's Digital Competitiveness (compared to the EU countries), section 4 examines Centru Region's Innovation Performance (compared to Romania and EU), while section 5 looks over Centru Region's Regional Competitiveness (compared to Romania and EU countries); the paper ends with conclusions.

\section{Centru Region-Romania. Brief Description}

Centru Region-Romania is one of Romania's eight Development Regions - along with: Nord-Est (North-East), Sud-Est (South-East), Sud Muntenia (South Muntenia), SudVest Oltenia (South-West Oltenia), Vest (West), Nord-Vest (North-West), and BucurestiIlfov; thanks to its location, Centru Region is bordered by six out of the other seven development regions of Romania (Bucuresti-llfov being the exception). Representing $14.3 \%$ of Romania's territory, while gathering $11.94 \%$ of Romania's population, Centru Region is composed of six counties - Alba, Brașov, Covasna, Harghita, Mureș and Sibiu (http://www.adrcentru.ro/wp-content/uploads/2019/12/Analiza-socioeconomica-a-RegiuniiCentru.pdf). Table 1 (based on most recent available data on Eurostat) provides a concise statistical profile of Centru Region-Romania - by placing it against the best and the worst performers / regions in the country, given the statistical domains and their main indicators. 
Table 1. Centru Region-Romania - Statistical Profile - compared to the best and the worst performers/regions in Romania

\begin{tabular}{|c|c|c|c|c|}
\hline $\begin{array}{l}\text { Statistical } \\
\text { domains }\end{array}$ & Indicators & $\begin{array}{l}\text { Lowest } \\
\text { Region }\end{array}$ & $\begin{array}{l}\text { Centru } \\
\text { Region }\end{array}$ & $\begin{array}{l}\text { Highest } \\
\text { Region }\end{array}$ \\
\hline Population & Population, total persons, 2019 & $\begin{array}{l}1777474 \\
\text { Vest }\end{array}$ & 2318272 & $\begin{array}{l}3198564 \\
\text { Nord-Est }\end{array}$ \\
\hline Economy & GDP (PPS per inhabitant), 2018 & $\begin{array}{l}12800 \\
\text { Nord-Est }\end{array}$ & 19200 & $\begin{array}{c}46800 \\
\text { Bucuresti-IIfov }\end{array}$ \\
\hline Education & $\begin{array}{l}\text { Young people neither in employment } \\
\text { nor in educational training ( } \% \text { of } \\
\text { population aged } 15-24), 2018\end{array}$ & $\begin{array}{c}7.9 \% \\
\text { Bucuresti-IIfov }\end{array}$ & $23.9 \%$ & $\begin{array}{l}23.9 \% \\
\text { Centru }\end{array}$ \\
\hline Health & $\begin{array}{l}\text { All causes of death (crude death } \\
\text { rate), } 2016\end{array}$ & $\begin{array}{c}1114.2 \\
\text { Bucuresti-IIfov }\end{array}$ & 1198.02 & $\begin{array}{c}1438.2 \\
\text { Sud-Muntenia }\end{array}$ \\
\hline $\begin{array}{l}\text { Labor } \\
\text { market }\end{array}$ & $\begin{array}{l}\text { Employment rate, from } 20 \text { to } 64 \\
\text { years, } 2018\end{array}$ & $\begin{array}{l}63.9 \% \\
\text { Centru }\end{array}$ & $63.9 \%$ & $\begin{array}{l}78.1 \% \\
\text { Nord-Est }\end{array}$ \\
\hline Tourism & $\begin{array}{lcr}\begin{array}{l}\text { Nights spent } \\
\text { accommodation }\end{array} & \text { in } & \text { tourist } \\
\text { inhabitants), } 2017 & & 1000\end{array}$ & $\begin{array}{c}681.5 \\
\text { Sud-Muntenia }\end{array}$ & 2500.3 & $\begin{array}{l}2500.3 \\
\text { Centru }\end{array}$ \\
\hline Agriculture & $\begin{array}{l}\text { Livestock farming, bovine animals } \\
\text { (1000 heads of livestock), } 2018\end{array}$ & $\begin{array}{l}5.3 \\
\text { Bucuresti-Ilfov }\end{array}$ & 345.7 & $\begin{array}{l}486.5 \\
\text { Nord-Est }\end{array}$ \\
\hline Transport & $\begin{array}{l}\text { Motorization rate (passenger cars } \\
\text { per } 1000 \text { inhabitants), } 2017\end{array}$ & $\begin{array}{l}227 \\
\text { Nord-Est }\end{array}$ & 309 & $\begin{array}{c}518 \\
\text { Bucuresti-IIfov }\end{array}$ \\
\hline $\begin{array}{l}\text { Science and } \\
\text { technology }\end{array}$ & $\begin{array}{l}\text { Human resources in science and } \\
\text { technology (\%of labor force), } 2018\end{array}$ & $\begin{array}{l}16.9 \\
\text { Nord-Est }\end{array}$ & 29.1 & $\begin{array}{c}50.8 \\
\text { Bucuresti-IIfov }\end{array}$ \\
\hline
\end{tabular}

Source: https://ec.europa.eu/eurostat/cache/RCl/\#?vis=nuts2.labourmarket\&lang=en

As Table 1 reveals, Tourism (expressed in Nights spent in tourist accommodation per 1000 inhabitants) is a relative strength of Centru Region compared to the other regions in Romania, while Education (expressed as percentage of young people aged 1524 neither in employment nor in educational training) and Labor market (expressed through employment rate from 20 to 64 years) seem to be Centru Region's relative weaknesses. By referring to people that are not "forced by circumstances" (school and/or work) to address the challenges of digitalization in a consistent manner, both these latter dimensions are critical - not only as regards the current status of digital transformation in Centru Region, but also considering the evolution towards digital maturity in the region; on the other hand, tourism has the potential of being capitalized as "digital" strength in the region - as tourism "was a consistent early adopter of new technologies and platforms" (https://www.unwto.org/digital-transformation).

In terms of Digital economy and society (Table 2) - the most relevant statistical domain for this paper - the indicators reveal no particular strength(s) and/or weakness(es) for Centru Region compared to the other development regions in Romania - considering neither the individuals' access (to internet / broadband) nor their Internet use (for different purposes: banking, civic or political participation, selling of goods/services, social networks, interactions with public authorities, ordering goods/services for private use). 
Table 2. Digital economy and society - Centru Region

\begin{tabular}{|c|c|c|}
\hline Indicators & $\begin{array}{l}\text { Centru } \\
\text { Region }\end{array}$ & $\begin{array}{l}\text { Romania } \\
\text { Range }\end{array}$ \\
\hline 1. Households with internet access (\% of private households), 2019 & $84 \%$ & $79-91 \%$ \\
\hline 2. Households with broadband access (\% of private households), 2019 & $80 \%$ & $77-91 \%$ \\
\hline 3. People who never used a computer (\% of people aged 16-74), 2017 & $28 \%$ & $10-37 \%$ \\
\hline $\begin{array}{l}\text { 4. People using the internet during the last three months (\% of people } \\
\text { aged 16-74), Frequency of internet access: daily, } 2019\end{array}$ & $57 \%$ & $49-65 \%$ \\
\hline $\begin{array}{l}\text { 5. People using the internet during the last three months (\% of people } \\
\text { aged 16-74), Internet use: Internet banking, } 2019\end{array}$ & $12 \%$ & $4-14 \%$ \\
\hline $\begin{array}{l}\text { 6. People using the internet during the last three months (\% of people } \\
\text { aged 16-74), Internet use: civic or political participation, } 2017\end{array}$ & $8 \%$ & $4-12 \%$ \\
\hline $\begin{array}{l}\text { 7. People using the internet during the last three months (\% of people } \\
\text { aged 16-74), Internet use: selling goods or services, } 2019\end{array}$ & $3 \%$ & $1-4 \%$ \\
\hline $\begin{array}{l}\text { 8. People using the internet during the last three months (\% of people } \\
\text { aged 16-74), Internet use: participating in social networks (creating } \\
\text { user profile, posting messages or other contributions to Facebook, } \\
\text { Twitter, etc.), } 2019\end{array}$ & $57 \%$ & $54-68 \%$ \\
\hline $\begin{array}{l}\text { 9. People using the internet during the last three months (\% of people } \\
\text { aged 16-74), Internet use: never, } 2019\end{array}$ & $18 \%$ & $8-25 \%$ \\
\hline $\begin{array}{l}\text { 10. People using the internet in the last } 12 \text { months for interaction with } \\
\text { public authorities (\% of people aged } 16-74), 2019\end{array}$ & $13 \%$ & $8-21 \%$ \\
\hline $\begin{array}{l}\text { 11. People using the internet in the last } 12 \text { months to order goods or } \\
\text { services for private use (\% of people aged } 16-74), 2019\end{array}$ & $27 \%$ & $18-31 \%$ \\
\hline
\end{tabular}

Source: https://ec.europa.eu/eurostat/cache/RCl/\#?vis=nuts2.infosoc\&lang=en

But all these data, in order to be relevant and meaningful, need to be: (a). put in context - the digital economy and society index (DESI), which is a "composite index that summarizes relevant indicators on Europe's digital performance and tracks the evolution of EU Member States in digital competitiveness" (https://ec.europa.eu/digitalsingle-market/en/desi); and (b). analyzed considering their impact - on innovation - as "key driver of competitiveness" (Dobrinsky, 2008) - and (regional) competitiveness viewed as "the ability of a region to offer an attractive and sustainable environment for firms and residents to live and work" (Annoni \& Dijkstra, 2019).

\section{Romania's Digital Competitiveness - Identifying the Gaps}

According to the most recently released Digital Economy and Society Index DESI 2020 - Romania ranks 26th out of the 28 EU member states (including the UK) (Figure 1) (https://ec.europa.eu/digital-single-market/en/desi). 
Figure 1. DESI 2020 - Romania compared to the EU countries and the EU average
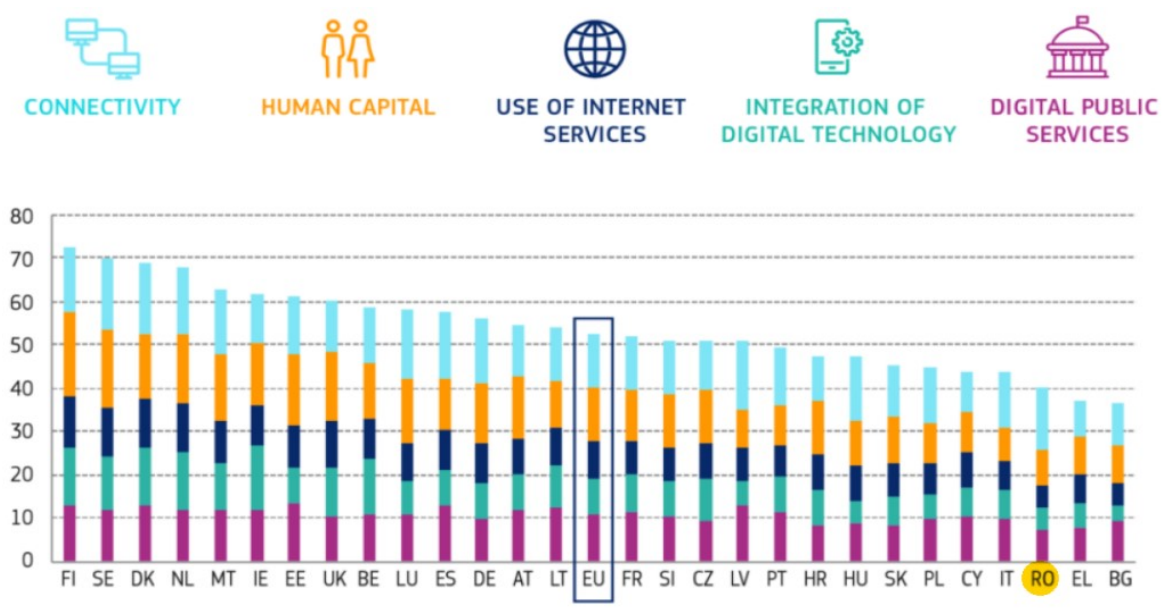

Source: https://ec.europa.eu/digital-single-market/en/desi

Thus, Romania's relative performance considering DESI is well below the European average, especially as concerns the dimensions Digital Public Services and Use of Internet Services - on which Romania is positioned the last among the EU countries; as concerns Human Capital and Integration of digital technology, Romania occupies the penultimate place in the EU. Only the Connectivity dimension places Romania above the EU average $\left(11^{\text {th }}\right.$ place in the EU) - which is a good prerequisite if considering the (imperative) need for accentuating digitalization, intensifying digital transformation and increasing competitiveness in the era of the $4^{\text {th }}$ Industrial Revolution.

Although the last three (chronologically speaking) DESI reports reveal a slight increase in Romania's overall score (from 35.1 in 2018 to 40.0 in 2020) - based on the improvements registered by all the five dimensions of DESI (Table 3 and Figure 2) compared to the dynamics registered by the EU countries it was not enough for Romania to improve its ranking among the EU countries; therefore, Romania has maintained its antepenultimate position among the EU countries.

Table 3. DESI 2018-2020 score - Romania versus EU

\begin{tabular}{|c|c|c|c|}
\hline \multirow{2}{*}{ DESI } & \multicolumn{2}{c|}{ Romania } & EU \\
\hline DESI 2020 & 26 & 40.0 & 52.6 \\
\hline DESI 2019 & 26 & 36.5 & 49.4 \\
\hline DESI 2018 & 26 & 35.1 & 46.5 \\
\hline
\end{tabular}

Source: https://ec.europa.eu/romania/news/20200611 raport rezilienta digitala ro 
Figure 2. DESI, by Main Dimensions of the DESI 2015-2020 - Romania

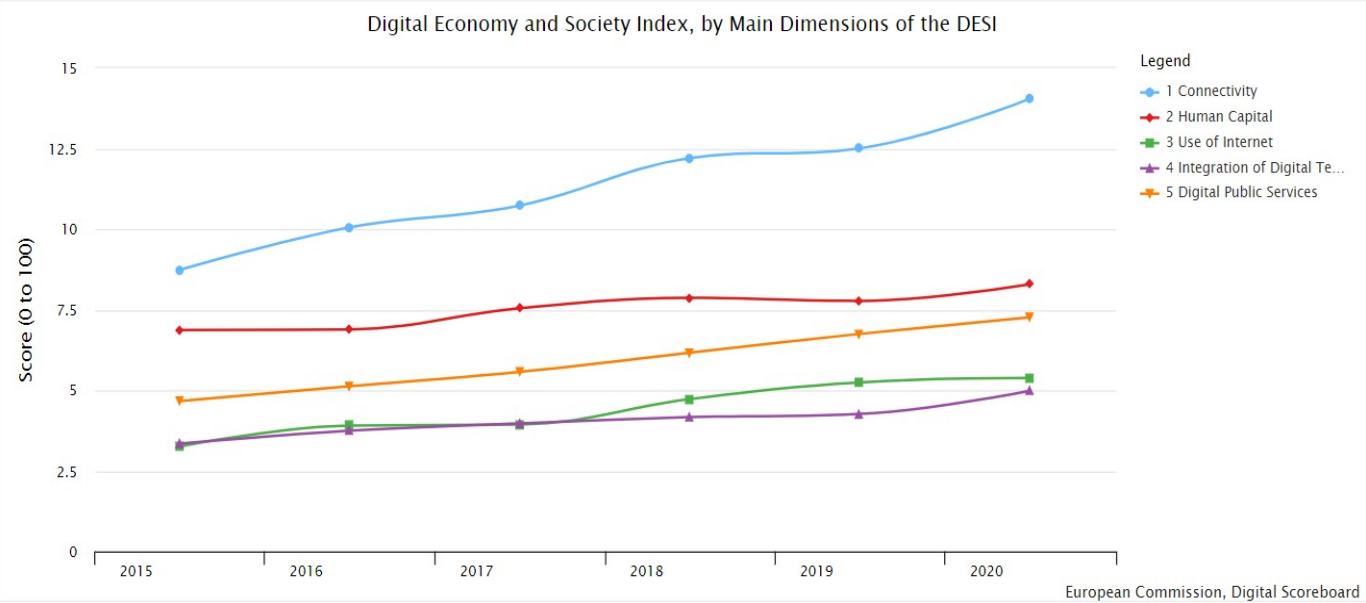

Source: https://ec.europa.eu/digital-single-market/en/desi

Despite the fact that the evolution of Romania's DESI components reveals increasing trends (for each one of them), the structural analysis of Romania's DESI in 2020 brings to light significant gaps - compared to the EU countries and/or the EU average (https://ec.europa.eu/romania/news/20200611 raport rezilienta digitala ro); thus, as concerns: (1) Connectivity: Romania has three indicators above the EU average (At least 100 Mbps fixed broadband take-up, Fixed Very High Capacity Network (VHCN) coverage, and Broadband price index), four indicators below the EU average (Overall fixed broadband take-up, Fast broadband (NGA) coverage, 4G coverage, and Mobile broadband take-up), and one indicator at the EU average (5G readiness); (2) Human Capital: Romania has one indicator above the UE average (ICT graduates), while five indicators are below the UE average (At least basic digital skills, Above basic digital skills, At least basic software skills, ICT specialists, and Female ICT specialists); (3) Use of Internet Services: Romania has two indicators above the EU average (Video calls, and Social networks), while nine indicators are below the EU average (People who have never used the internet, Internet users, News, Music, videos and games, Video on demand, Doing an online course, Banking, Shopping, and Selling online); (4) Integration of digital technology: all the seven indicators are placing Romania below the EU average (Electronic information sharing, Social media, Big data, Cloud, SMEs selling online, eCommerce turnover, and Selling online cross-border); (5) Digital public services: Romania has one indicator above the EU average (e-Government users), and four indicators below the EU average (Pre-filled forms, Online service completion, Digital public services for businesses, and Open data).

Against this background, it is essential for Romania to reduce the digital economy and society related gaps - in order for the country to increase its innovation-based competitiveness (following digital transformation), as well as its contribution to Europe's evolution as global (digital) innovation (and competitiveness) pole. 


\section{Centru Region's Innovation Performance compared to Romania and EU}

The European Commission Regional Innovation Scoreboard (RIS) 2019 which is "assessing the innovation performance of European regions" (https://ec.europa.eu/growth/industry/policy/innovation/regional en) - certifies Centru Region-Romania (RO12) as a "modest innovator" - whose innovative performance has fallen compared to 2011 by $(-10,8 \%)$ (Table 4$)$. Given its overall innovative performance (relative to EU), Bucuresti-Ilfov - which is "performing more than 3.6 times as well as the lowest performing region, Sud-Vest Oltenia" (Hollanders, Es-Sadki, \& Merkelbach, 2019) is the only Development Region in Romania which qualifies as a moderate innovator. Withal, Romania is a modest innovator, with the lowest score in EU - well below $50 \%$ of EU's average (34.4 overall score in 2019); at the other end of the spectrum are the innovation leaders - with innovative performance above $120 \%$ of the EU average, where Sweden (153.12 overall score) has the lead (Hollanders, Es-Sadki, \& Merkelbach, 2019).

Table 4. Regional Innovation Scoreboard 2019 - Performance groups

\begin{tabular}{|l|l|c|c|c|c|}
\hline & & $\begin{array}{c}\text { "2011" - score } \\
\text { relative to EU } \\
2011\end{array}$ & $\begin{array}{c}\text { "2019" - score } \\
\text { relative to EU } \\
\mathbf{2 0 1 1}\end{array}$ & $\begin{array}{c}\text { "2019" - score } \\
\text { relative to EU } \\
\mathbf{2 0 1 9}\end{array}$ & $\begin{array}{c}\text { Performance } \\
\text { group }\end{array}$ \\
\hline EU28 & EU28 & $\mathbf{1 0 0 , 0}$ & $\mathbf{1 0 4 , 7}$ & $\mathbf{1 0 0 , 0}$ & -- \\
\hline RO11 & Nord-Vest & 40,8 & 31,1 & 29,7 & Modest - \\
\hline RO12 & Centru & $\mathbf{3 9 , 4}$ & $\mathbf{2 8 , 6}$ & $\mathbf{2 7 , 3}$ & Modest - \\
\hline RO21 & Nord-Est & 41,5 & 22,5 & 21,5 & Modest - \\
\hline RO22 & Sud-Est & 42,7 & 23,1 & 22,1 & Modest - \\
\hline RO31 & Sud - Muntenia & 36,1 & 19,3 & 18,4 & Modest - \\
\hline RO32 & Bucuresti - Ilfov & 62,0 & 54,1 & 51,6 & Moderate - \\
\hline RO41 & Sud-Vest Oltenia & 31,4 & 15,0 & 14,3 & Modest - \\
\hline RO42 & Vest & 40,0 & 34,3 & 32,8 & Modest - \\
\hline
\end{tabular}

Source : https://ec.europa.eu/growth/industry/policy/innovation/regional_en

By components, the radar graph (Figure 3) - Centru Region's Regional Innovation Index (RII) relative to Romania (the orange line) and to EU (the blue line) - and the full data table (Figure 4) - capturing all the indicators for all of the Romania's Development Regions - reveal Employment in medium and high-tech manufacturing and knowledge-intensive services (102.74 score) as relative strength (although other regions in Romania - Vest and Bucuresti-Ilfov - are performing better than Centru Region) - on one hand, and Innovative SMEs collaborating with others (3.24 score) and R\&D expenditures in the public sector (14.04 score) as absolute weakness - on the other hand. 
Figure 3. Centru Region - Regional Innovation Profile 2019 - compared to Romania and EU

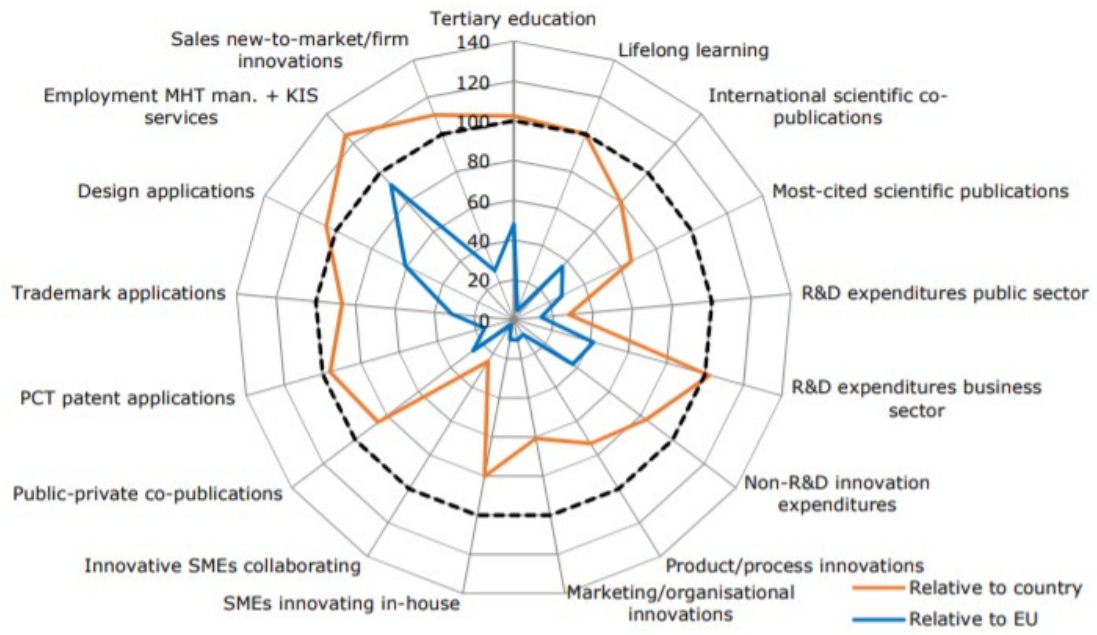

Source: https://ec.europa.eu/docsroom/documents/35937

Figure 4. Romania - Regional Profiles according to RIS 2019

\begin{tabular}{|c|c|c|c|c|c|c|c|c|c|}
\hline Trademark applications & 46.46 & 38.25 & 30.26 & 11.78 & 18.71 & 72.99 & 20.06 & 38.02 & \\
\hline Scientific co-publications & 80.59 & 49.83 & 52.85 & 26.06 & 14.92 & 120.54 & 29 & 65.65 & 50 \\
\hline Sales of new-to-market and new-to-... & 18.59 & 27.14 & 33.21 & 41.14 & 21.98 & 23.42 & 13.88 & 14 & \\
\hline SMEs innovating in-house & 17.99 & 10.13 & 8.86 & 31.4 & 3.85 & 12.35 & 7.4 & 4.63 & 100 \\
\hline$R \& D$ expenditure public sector & 45.52 & 14.04 & 45.52 & 25.67 & 17.35 & 84.22 & 36.57 & 34.59 & \\
\hline$R \& D$ expenditure business sector & 20.03 & 44.83 & 11.69 & 1.62 & 50.27 & 64.86 & 5.79 & 50.27 & 150 \\
\hline Public-private co-publications & 18.2 & 27.01 & 11.46 & 13.19 & 11.9 & 82.97 & 0 & 0 & \\
\hline Product or process innovators & 15.97 & 8.81 & 9.13 & 29.29 & 4.48 & 12.69 & 6.4 & 4.48 & \\
\hline Population with tertiary education & 51.48 & 51.9 & 17.3 & 9.7 & 6.33 & 157.81 & 30.8 & 43.04 & 250 \\
\hline Non-R\&D innovation expenditures & 35.61 & 36.42 & 43.05 & 81.39 & 28.21 & 44.89 & 12.72 & 35.74 & \\
\hline Most-cited publications & 48.34 & 28.47 & 42.97 & 41.64 & 35.06 & 41.41 & 31.36 & 55.44 & \\
\hline Marketing or organisational innovators & 27 & 9.44 & 24.46 & 20.05 & 3.89 & 15.02 & 0 & 14.87 & \\
\hline Lifelong learning & 4.95 & 4.95 & 4.95 & $\mathbf{0}$ & 7.92 & 6.93 & 0.99 & 4.95 & \\
\hline Innovative SMEs collaborating with ot... & 20.95 & 3.24 & 14.21 & 7.87 & 4.23 & 19.42 & 19.91 & 8.89 & \\
\hline Innovation index & 31.06 & 28.58 & 22.52 & 23.14 & 19.29 & 54.08 & 14.98 & 34.35 & \\
\hline Employment medium and high tech... & 62.6 & 102.74 & 14.25 & 52.56 & 84.49 & 157.47 & 37.47 & 209.47 & \\
\hline EPO patent applications & 14.83 & 14.35 & 11.13 & 10.03 & 13.12 & 19.45 & 9.69 & 17.88 & \\
\hline Design applications & 49.8 & 58.88 & 30.88 & 6.83 & 21.11 & 86.37 & 14.71 & 35.3 & \\
\hline
\end{tabular}

Source: https://interactivetool.eu/RIS/RIS 2.html\#d 
Both the decreasing of the innovation performance and the (relatively) low values of all the Centru Region's innovation related indicators (Population with tertiary education, Lifelong learning, International Scientific co-publications, Most-cited publications, R\&D expenditure public sector, R\&D expenditure business sector, Non-R\&D innovation expenditures, Product or process innovations, Marketing or organizational innovations, SMEs innovating in-house, Innovative SMEs collaborating with others, Public-private copublications, PCT patent applications, Trademark applications, Design applications, Employment in medium and high-tech manufacturing and knowledge-intensive services, and Sales new-to-market / firm innovations) - ask for a turnaround innovation strategy (built on the region's strengths and capitalizing on its opportunities, while addressing the weaknesses and mitigating the threats) - able to stimulate and increase the pace of innovation at micro level (businesses / public administrations) - through consistent / strategic endeavors towards innovation - in order to close the innovation gaps and to better connect Centru Region to the realities and trends of nowadays.

\section{Regional Competitiveness of Centru Region compared to Romania and EU}

The Regional Competitiveness Index $(\mathrm{RCl})$ - measuring the major factors of competitiveness (through 74 indicators, grouped into 11 pillars organized into three subindexes: basic, efficiency and innovation factors of competitiveness) - makes it possible for all the EU regions to assess and compare (both in time and in space) the fundamentals of their competitiveness, while suggesting intervention areas for policy makers (https://cohesiondata.ec.europa.eu/stories/s/Regional-Competitiveness-Index-2019/363v4uq6/). As regards the most recent $\mathrm{RCI}$ (2019), Centru Region ranks the 249 out of the 268 EU regions - with a 13.18 score, which is quite below Romania's average $\mathrm{RCI}$ score (17.84) and far away from the EU28 RCl 2019 score (60.3) (Table 5, Figures 5-6); moreover, the dynamics of Romania regions' $\mathrm{RCl}$ z-score - and particularly of Centru Region (Figure 7) - are not encouraging.

Table 5. RCI - Centru Region compared to Romania and EU (2019) - values

\begin{tabular}{|l|c|c|c|}
\hline Pillars, Sub-indexes, \& RCI & RO12: Centru & RO & EU28 \\
\hline 01_Institutions & 16,09 & 14,60 & 49,5 \\
\hline 02_Macroeconomic Stability & 48,61 & 48,61 & 61,7 \\
\hline 03_Infrastructure & 0,63 & 8,79 & 50,1 \\
\hline 04_Health & 22,10 & 23,92 & 70,9 \\
\hline 05_Basic Education & 0,00 & 0,00 & 54,9 \\
\hline 06_Higher Education and Lifelong Learning & 26,87 & 30,73 & 58,5 \\
\hline 07_Labour Market Efficiency & 57,89 & 60,58 & 69,1 \\
\hline 08_Market Size & 39,06 & 43,37 & 65,1 \\
\hline 09_Technological Readiness & 15,60 & 19,50 & 65,1 \\
\hline 10_Business Sophistication & 5,37 & 7,05 & 41,4 \\
\hline 11_Innovation & 17,33 & 17,17 & 49,2 \\
\hline
\end{tabular}




\begin{tabular}{|l|c|c|c|}
\hline 12_Basic Sub-index & 2,31 & 4,56 & 57,2 \\
\hline 13_Efficiency Sub-index & 38,26 & 42,98 & 68,1 \\
\hline 14_Innovation Sub-index & 8,40 & 10,51 & 55,8 \\
\hline 15_RCI 2019 & $\mathbf{1 3 , 1 8}$ & $\mathbf{1 7 , 8 4}$ & $\mathbf{6 0 , 3}$ \\
\hline
\end{tabular}

Source of data: https://cohesiondata.ec.europa.eu/Other-RCl/European-Regional-CompetitivenessIndex-2019-index/if3f-yweu

Figure 5. RCI - Centru Region compared to Romania and EU (2019) - radar chart

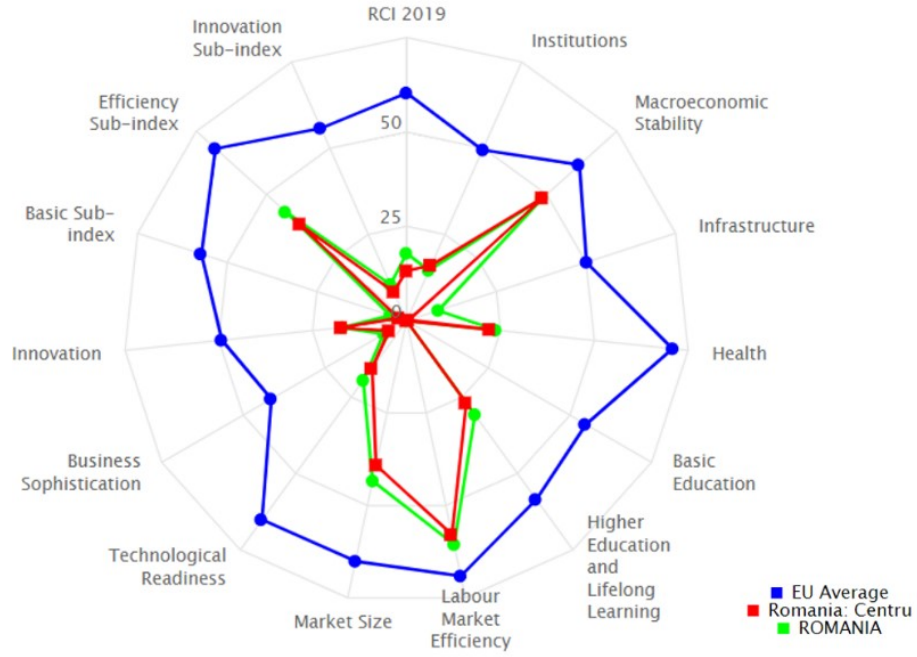

Source: https://ec.europa.eu/regional policy/en/information/maps/regional competitiveness/\#4

Figure 6. RCI - Centru Region compared to all Romania's regions (2019) - values

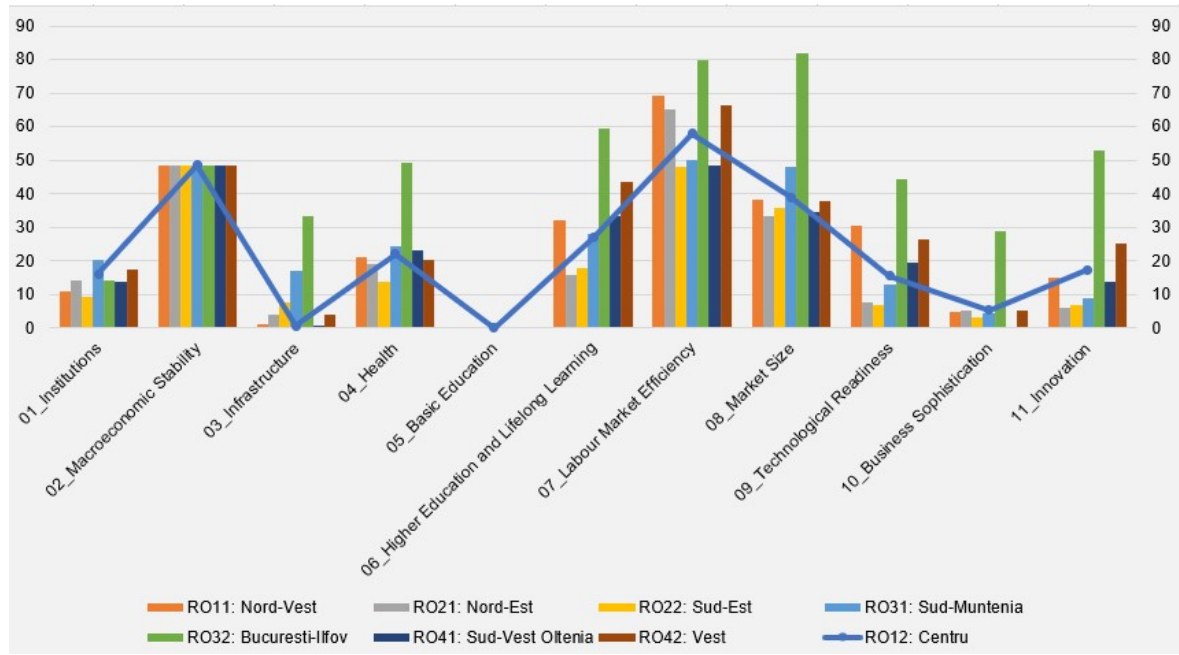

Source of data: https://cohesiondata.ec.europa.eu/Other-RCI/European-Regional-CompetitivenessIndex-2019-index/if3f-yweu 
Figure 7. RCI - Centru Region compared to all Romania's regions - time evolution

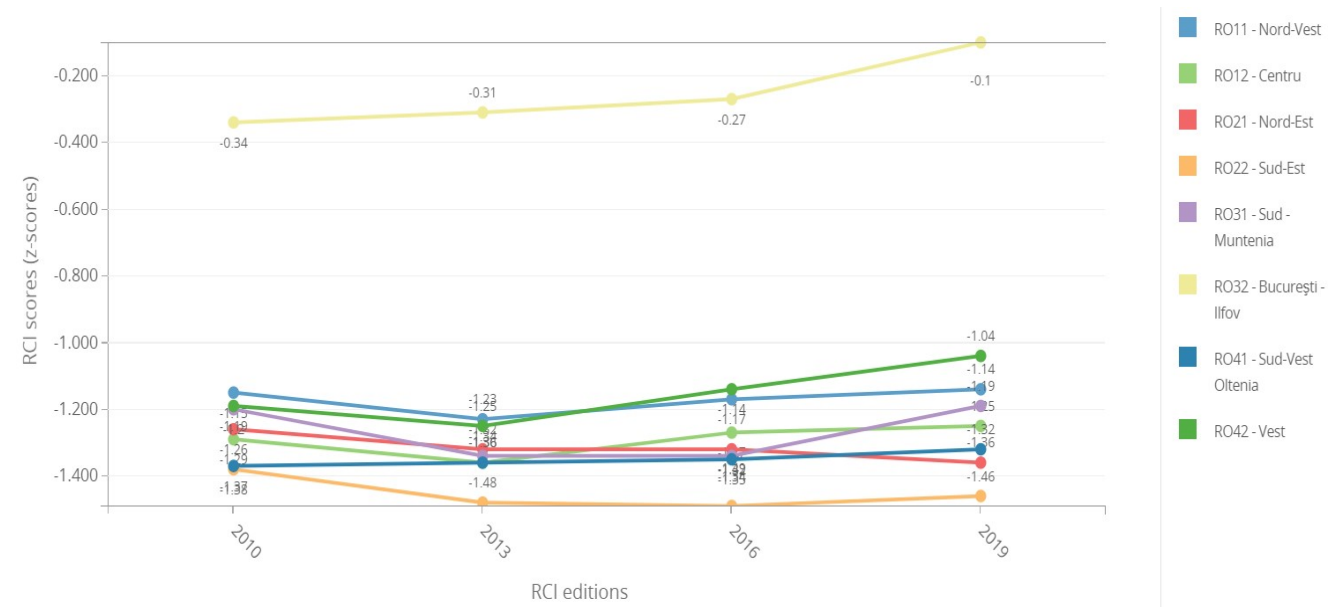

Source: https://cohesiondata.ec.europa.eu/stories/s/Regional-Competitiveness-Index-2019/363v4uq6/

On the other hand, when compared to its peer (European) regions (Peloponnisos; Kujawsko-pomorskie; Opolskie; Calabria; Kriti; Lubuskie; Východné Slovensko; Jadranska Hrvatska; Zachodniopomorskie; Kentriki Makedonia; Guyane; Nord-Vest; Mazowiecki regionalny; Sicilia and Thessalia), Centru Region-Romania: (a). is not overperforming them regarding none of the 11 pillars of competitiveness; (b). is similar to them regarding three basic dimensions (Institutions, Macroeconomic stability, Health), all of the efficiency dimensions (Higher Education and lifelong learning, Labor Market Efficiency, Market size), and two innovation dimensions (Technological Readiness and Innovation); (c). is underperforming them on two basic dimensions (Infrastructure and Basic education), and one innovation dimension (Business sophistication) (https://ec.europa.eu/regional policy/sources/docgener/work/rci2019 scorecards.pdf).

\section{Conclusions}

Fitting Europe for the digital age - through "digital transformation that will benefit everyone" - is quite a challenging and ambitious strategic EU goal, as the disparities and gaps existing amongst Europe's countries and regions are significant - in terms of both levels of digital maturity and resources to be allocated for this endeavor. The good news is that all the six European Commission's priorities - A European green deal, A Europe fit for the digital age, An economy that works for people, A stronger Europe in the world, Promoting our European way of life, and A new push for European democracy (https://ec.europa.eu/info/strategy/priorities-2019-2024 en) - have the vocation of complementing each other (thus generating ripple and network effects); though, the not so good news is the possibility for some of the national EU actors - companies / public administrations - not to be aware that digital transformation is needed (to different degrees and in different forms) at their level. Considering the brief analysis made for 
Centru Region-Romania, the needs for digital transformation are more than obvious and stringent - in order for the region (and consequently the country) to align to the imperatives of the digital age; not covering the gaps will not only result in efficiency related losses (higher costs), but also in uncertainties regarding the future of a specific company/entity.

\section{References}

Agenția pentru Dezvoltare Regională Centru (2019). Analiza socioeconomică a Regiunii Centru. (Regional Development Agency - Centru. Socio-economic Analysis of Centru Region) http://www.adrcentru.ro/wp-content/uploads/2019/12/Analiza-socioeconomica-a-RegiuniiCentru.pdf

Agenția pentru Dezvoltare Regională Centru (2020). Planul de Dezvoltare al Regiunii Centru 2021-2027. (Regional Development Agency - Centru. Development Plan for Centru Region). http://www.adrcentru.ro/dezvoltare-regionala-cat/pdr-centru-2021-2027/

Annoni, P., \& Dijkstra, L. (2019). The EU Regional Competitiveness Index 2019. https://ec.europa.eu/regional policy/sources/docgener/work/2019 03 rci2019.pdf

Comisia Europeana. (2020). Indicele economiei și societății digitale (DESI) 2020: România pe locul 26. https://ec.europa.eu/romania/news/20200611 raport rezilienta digitala ro

Dobrinsky, R. (2008). Innovation as a key driver of competitiveness. UNECE Annual Report Economic Essays, 6, 53-59.

European Commission. (2020). The Digital Economy and Society Index (DESI). https://ec.europa.eu/digital-single-market/en/desi

European Commission. (2019). The EU Regional Competitiveness Index (RCI) 2019. https://ec.europa.eu/regional policy/en/information/maps/regional competitiveness/

European Commission. (2019). Regional Innovation Scoreboard (RIS) 2019. https://ec.europa.eu/growth/industry/policy/innovation/regional en

European Commission. Shaping Europe's Digital Future. The European Digital Strategy. https://ec.europa.eu/digital-single-market/en/content/european-digital-strategy

European Commission. (2019) European Regional Competitiveness Index. Scorecards. https://ec.europa.eu/regional policy/sources/docgener/work/rci2019 scorecards.pdf

European Commission. Six Commission Priorities for 2019-24. https://ec.europa.eu/info/strategy/priorities-2019-2024 en

Hollanders, H., Es-Sadki, N., \& Merkelbach, I. (2019). Regional Innovation Scoreboard 2019. https://ec.europa.eu/growth/sites/growth/files/ris2019.pdf

World Tourism Organization. A United Nations Specialized Agency (UNWTO). Digital Transformation. https://www.unwto.org/digital-transformation

*** The EU Regional Competitiveness Index 2019. https://cohesiondata.ec.europa.eu/stories/s/Regional-Competitiveness-Index-2019/363v$\underline{4 u q 6 /}$

*** Regional Innovation Scoreboard 2019. About the Data. https://interactivetool.eu/RIS/RIS 2.html\# 